\title{
Removal of heavy metals from tannery effluent using chitosan-g-poly(butyl acrylate)/bentonite nanocomposite as an adsorbent
}

\author{
R. Nithya and P. N. Sudha*
}

\begin{abstract}
In the present era, due to industrial revolution in the developing countries like India, the ground water system has been largely polluted. Tannery effluent is a major source of aquatic pollution, and a large number of tanneries are scattered all over India particularly in Tamilnadu, Uttar Pradesh and West Bengal. This work deals with the removal of heavy metals chromium and lead and the reduction of the important physicochemical parameters like total dissolved solid (TDS), total suspended solid (TSS), total solids (TS), biochemical oxygen demand (BOD), chemical oxygen demand (COD), total hardness, salinity, turbidity and electrical conductivity from the tannery wastewater by using chitosan-g-poly(butyl acrylate)/bentonite nanocomposite as an adsorbent. The batch system was used to conduct the biosorption experiments. The influence of different experimental parameters, such as contact time, $\mathrm{pH}$ and amount of adsorbent, was evaluated. The results showed that the prepared nanocomposite can be used efficiently for the treatment of tannery wastewater containing heavy metals.
\end{abstract}

Keywords: Tannery effluent, Physicochemical parameters, Heavy metal, Chromium, Lead

\section{Background}

Due to the rapid growth of tannery industries and pollution-provoking factories, it has become mandatory to realise the perilous reactions of toxic organic compounds and heavy metal ions in the water resources and take drastic steps to remove such pollutions from water to save mankind and environment. It was found that the pollutions caused by Lead and Chromium are found to be very crucial and need to be removed, failure of which would cause very baneful effects. Hexavalent chromium, due to the presence of mutagenic and carcinogenic properties, causes liver damage, pulmonary congestion, edema and skin irritation, resulting in ulcer formation (Raji and Anirudhan 1998). The World Health Organization (WHO) has recommended a maximum level of $0.05 \mathrm{mg} / \mathrm{l}$ of $\mathrm{Cr}$ (VI) in drinking water (Bhaumik et al. 2011) and $0.1 \mathrm{mg} / \mathrm{l}$ in surface water (Guidelines for Drinking-Water Quality 2006). The liver, kidney and

\footnotetext{
*Correspondence: drparsu8@gmail.com

PG and Research Department of Chemistry, D.K.M College for Women, Vellore, Tamil Nadu, India
}

reproductive system are affected severely by the toxic effect of lead, so also, the basic cellular processes and functions of the brain get negatively affected (Kushwaha et al. 2012). According to the $\mathrm{WHO}$, the maximum permissible limit of lead for drinking water is $3-10 \mu \mathrm{g} / \mathrm{l}$ (Needleman 1999) and $0.1 \mathrm{mg} / \mathrm{l}$ for inland surface water. Currently, biopolymers are industrially attractive because of their capacity to bind transition metal ions and are environmentally safe. One among the biopolymers is chitosan, a linear polysaccharide, composed of glucosamine and $N$-acetyl glucosamine units linked by $\beta(1-4)$ glycosidic linkage. It has emerged as one of the low-cost adsorbents for the removal of heavy metals and dyes. Though it is affordable in terms of cost and is non toxic, it is strongly $\mathrm{pH}$ dependent and very much susceptible to biodegradation (Mi et al. 2002; Ravi Kumar 2000), thus limiting its practical use as adsorbent. Hence, chemical modification by grafting (Mishra et al. 2008; Srivastava et al. 2009) is one of the promising techniques to improve the physicochemical properties and stability of chitosan. 
Table 1 Initial parameters of tannery wastewater

\begin{tabular}{|c|c|c|c|}
\hline \multirow[t]{2}{*}{ Parameters } & \multirow[t]{2}{*}{ Raw effluent collected } & \multicolumn{2}{|c|}{ Maximum tolerance limits for industrial effluents discharged (mg/l) } \\
\hline & & Into inland surface water & Into public sewers \\
\hline \multicolumn{4}{|l|}{ Physical parameters } \\
\hline Colour & Blackish colour & Colourless & - \\
\hline Odour & Disagreeable smell & Odourless & Unobjectionable \\
\hline $\mathrm{pH}$ & 7.43 & $5.5-9.0$ & $5.5-9.0$ \\
\hline \multicolumn{4}{|l|}{ Chemical parameters } \\
\hline Electrical conductivity $(\mathrm{EC})(\mathrm{mS} / \mathrm{cm})$ & 27.3 & 0.288 & - \\
\hline Biochemical oxygen demand (BOD) (mg/l) & 1250 & 30 & 350 \\
\hline Chemical oxygen demand (COD) (mg/l) & 4210 & 250 & - \\
\hline Total dissolved solids (TDS) (mg/l) & 15,900 & 2100 & 2100 \\
\hline Total solids (TS) (mg/l) & 31,740 & 2200 & - \\
\hline Total hardness (TH) (mg/l) & 923 & 600 & 300 \\
\hline Turbidity (NTU) & 453 & 10 & 5 \\
\hline Sodium (mg/l) & 5000 & - & 60 \\
\hline Chromium (Cr) (mg/l) & 1055 & 0.1 & 2.0 \\
\hline Lead $(\mathrm{Pb})(\mathrm{mg} / \mathrm{l})$ & 0.43 & 0.1 & 1.0 \\
\hline
\end{tabular}

Values expressed are as per the regulations given by (1) ISI standards for disposal of industrial wastewater. BIS (IS: 10500: 1991) and (2) Central Pollution Control Board. (1986), Pollution Control Acts, Rules, and Notifications issued there under. Fourth edition pp. 358-359. New Delhi, CPCB, Ministry of Environment and Forests. 897 pp

The syntheses of organic-inorganic polymeric materials have gained much attention recently for the removal of heavy metals from the wastewater because of their low cost, high mechanical resistance (Thambiannan et al. 2013; Junping et al. 2007) and effective adsorption of dyes (Mouzdahir et al. 2010). Bentonite is one of the most popular clay rocks with exceptional adsorption properties due to its large surface area (Schütz et al. 2013). It is a type of alumino silicate in the ratio of 2:1; its unit layer consists of one $\mathrm{Al}^{3+}$ octahedral sheet between two $\mathrm{Si}^{4+}$ tetrahedral sheets. However, negatively charged surface and large amount of exchangeable cations make natural bentonite highly hydrophilic, and its surface is covered with a layer of water, blocking, in part, its adsorption capability for organic pollutants. Moreover, it swells and form very stable colloidal suspension when it comes into contact with water, which causes the solid-liquid separation very difficult after adsorption (Wang et al. 2014). Hence, bentonite can be used as fillers in various polymer matrices to prepare nanocomposites because the functional groups of bentonite such as SiAOASi can interact strongly with functional groups in polymer matrices such as $\mathrm{AOH}$, $\mathrm{ANH}_{2}, \mathrm{ACOOH}$ and $N$-acetyl glucosamine units (Darder et al. 2005). A different composite with chitosan has been done by several researchers (Vanamudan et al. 2014; Abdel Khalek et al. 2012; Thayyath Sreenivasan Anirudhan et al. 2010).

The objective of this work is to use the novel adsorbent, chitosan-grafted-poly(butyl acrylate)/bentonite nanocomposite (Cs-g-PBA/bent) which is so far not known as reported for the removal of heavy metal $\mathrm{Cr}(\mathrm{VI})$ and $\mathrm{Pb}(\mathrm{II})$ ions from the industrial effluent rather than other

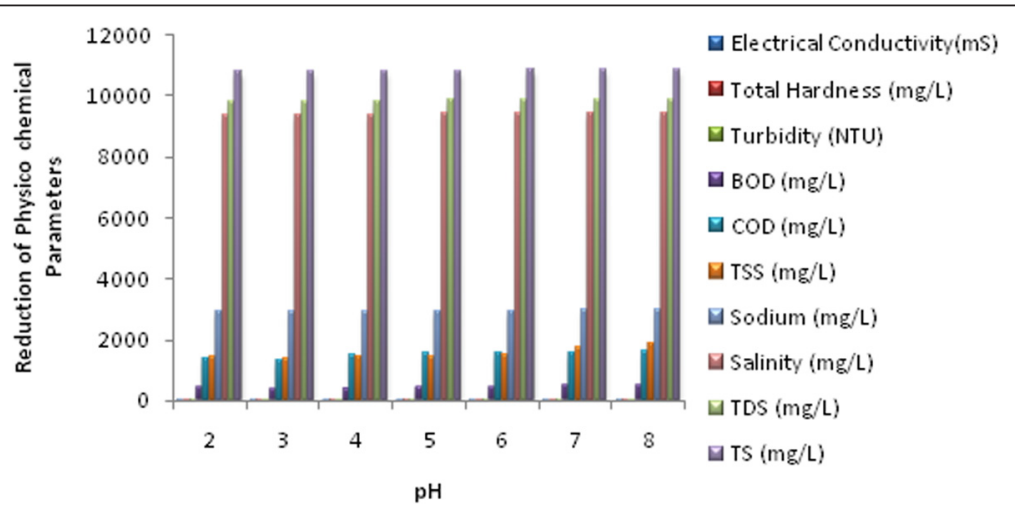

Fig. 1 Effect of $\mathrm{pH}$ on reduction of physicochemical parameters 


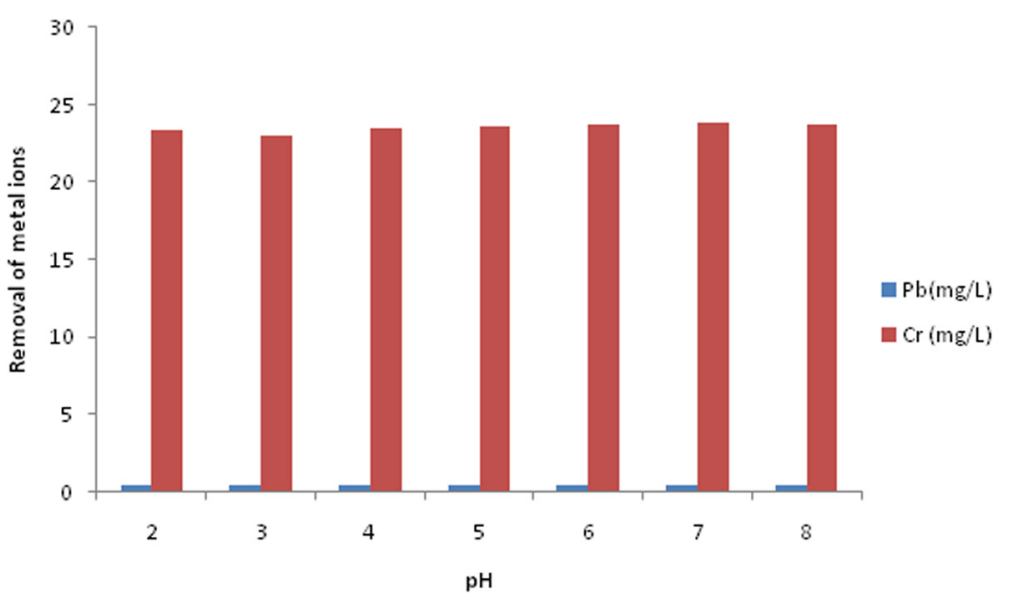

Fig. 2 Effect of pH on removal of metal ions

physicochemical parameters. But, the other physicochemical parameters are used to check the validity of Cs-g-PBA/ bent nanocomposite for the removal of $\mathrm{Cr}(\mathrm{VI})$ and $\mathrm{Pb}(\mathrm{II})$ in a tannery industry wastewater.

\section{Methods}

\section{Materials}

Chitosan (CS) (degree of deacetylation $=95 \%$ determined by $1 \mathrm{H}-\mathrm{NMR}$ and molecular weight $13.45 \times$ $104 \mathrm{Da}$ ) was purchased from India Sea Foods, Kerela, India. Ceric ammonium nitrate was purchased from Thomas Baker pvt Ltd. Acetic acid and glutaraldehyde was purchased from Sisco Research laboratories Pvt ltd. Bentonite was purchased from Aryem chemicals, Chennai.

\section{Methods}

Preparation of chitosan-g-poly(butyl acrylate)

A known amount of chitosan $(0.5 \mathrm{~g})$ was dissolved in a known volume $(30 \mathrm{ml})$ of $2 \%$ aqueous acetic acid. $\mathrm{N}$ -
Butyl acrylate $(0.6 \mathrm{ml}$ dissolved in $20 \mathrm{ml}$ ethanol) was added, and then, a freshly prepared solution of ceric ammonium nitrate (CAN) in $1 \mathrm{~N}$ nitric acid was added drop by drop with continuous stirring for $30 \mathrm{~min}$. The reaction was stopped, and the product was precipitated using $2 \mathrm{~N}$ sodium hydroxide solution with vigorous stirring. The precipitate was washed with distilled water for several times and filtered.

\section{Synthesis of chitosan-grafted poly (butyl acrylate)/bentonite (Cs-g-PBA/bent) nanocomposites}

Bentonite powder (bent) was heated at $110{ }^{\circ} \mathrm{C}$ for $1 \mathrm{~h}$ to activate the surface. A known amount of bentonite $(1 \mathrm{~g})$ was immersed in distilled water to make a slurry. About $1 \mathrm{~g}$ of poly(butyl acrylate) grafted chitosan was dissolved in $(5 \%, v / v)$ acetic acid. This solution was then added to the slurry and the mixture was stirred for $30 \mathrm{~min}$. Five millilitres of $25 \%$ glutaraldehyde was then added and stirred vigorously for $5 \mathrm{~min}$. The mixture was stirred and soaked in an ultrasonic bath for $30 \mathrm{~min}$. The

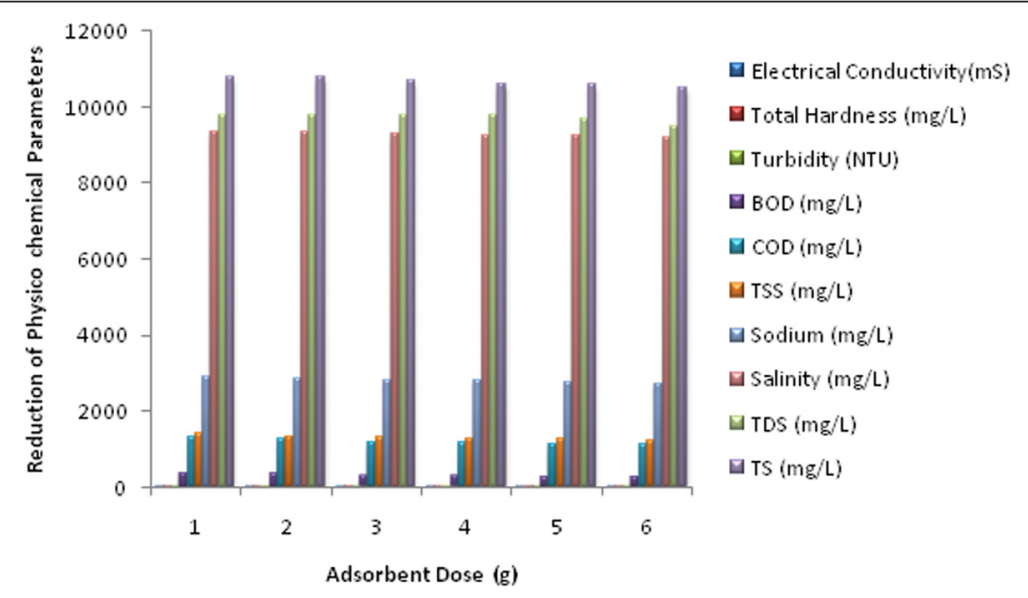

Fig. 3 Effect of adsorbent dose on reduction of physicochemical parameters 


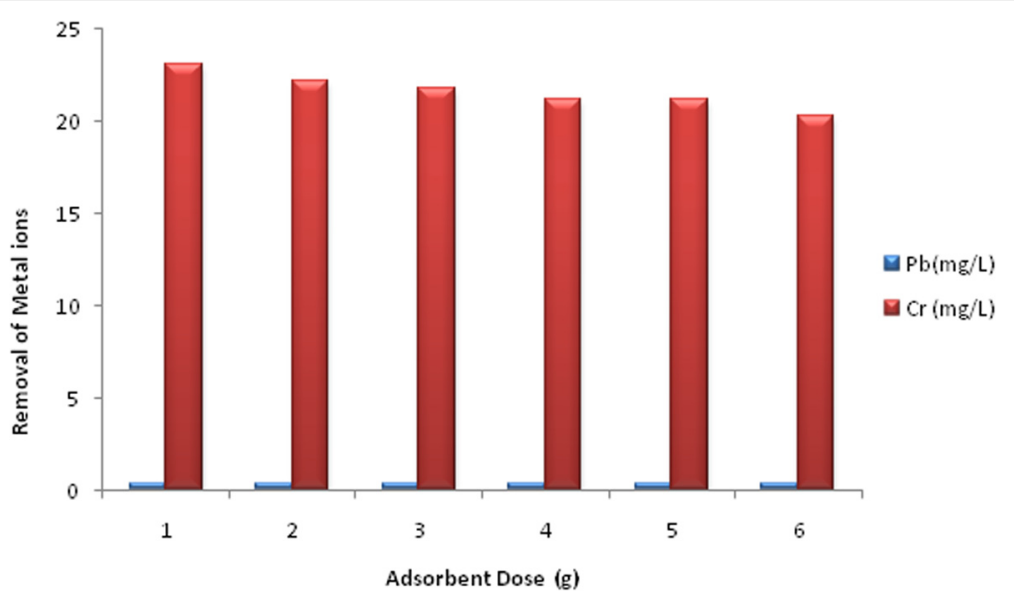

Fig. 4 Effect of adsorbent dose on removal of metal ions

temperature of the dispersion was at room temperature $\left(25{ }^{\circ} \mathrm{C}\right)$. This mixture was then washed with water and dried in oven at $50{ }^{\circ} \mathrm{C}$ to get Cs-g-PBA/bent powder. By analysing the powder with DLS method, the particle size was found to be $679.3 \mathrm{~nm}$, and hence, this powder would be more suitable for sorption studies.

\section{Batch adsorption experiments}

The batch adsorption experiments were conducted in $250-\mathrm{ml}$ conical flasks containing $100 \mathrm{ml}$ of tannery wastewater using $1 \mathrm{~g}$ of Cs-g-PBA/bent nanocomposite adsorbent. The flasks were agitated in an orbit shaker at room temperature. Effect of initial $\mathrm{pH}$ was studied by varying solution $\mathrm{pH}$ from 2 to 8 at the sorbent dosage of $1 \mathrm{~g} / 100 \mathrm{ml}$ for $1 \mathrm{~h}$ contact time. The $\mathrm{pH}$ of wastewater was adjusted by using $0.1 \mathrm{~N} \mathrm{HCl}$ or $0.1 \mathrm{~N} \mathrm{NaOH}$. The effect of contact time and adsorbent dose on the sorption capacity of sorbent was studied in the range 1-6 h and 1-6 g. After the period, the solution was filtered using Whatman filter paper no. 42 and the filtrate was analysed for physicochemical parameters and heavy metals chromium and lead. The adsorption removal percentage of various physicochemical parameters and heavy metals in a tannery industry wastewater was calculated by using the following formula:

$$
\% \text { Removal }=\frac{\text { initial } \text { concentration }- \text { final concentration }}{\text { initial } \text { concentration }} \times 100
$$

\section{Collection of sample}

The sample was collected from Ranipet (Ranipettai) a suburban town, which is a major industrial area located in Wallajah taluk, Vellore district, Tamil Nadu, at $79^{\circ}$ $19^{\prime}-79^{\circ} 22^{\prime} \mathrm{E}$ longitude and $12^{\circ} 53^{\prime}-12^{\circ} 57^{\prime} \mathrm{N}$ latitude and is situated $114 \mathrm{~km}$ west of Chennai. More than 200 tannery industrial units were located in and around this town. It is one of the biggest exporting centres of tanned leather in India and discharging their effluents on the

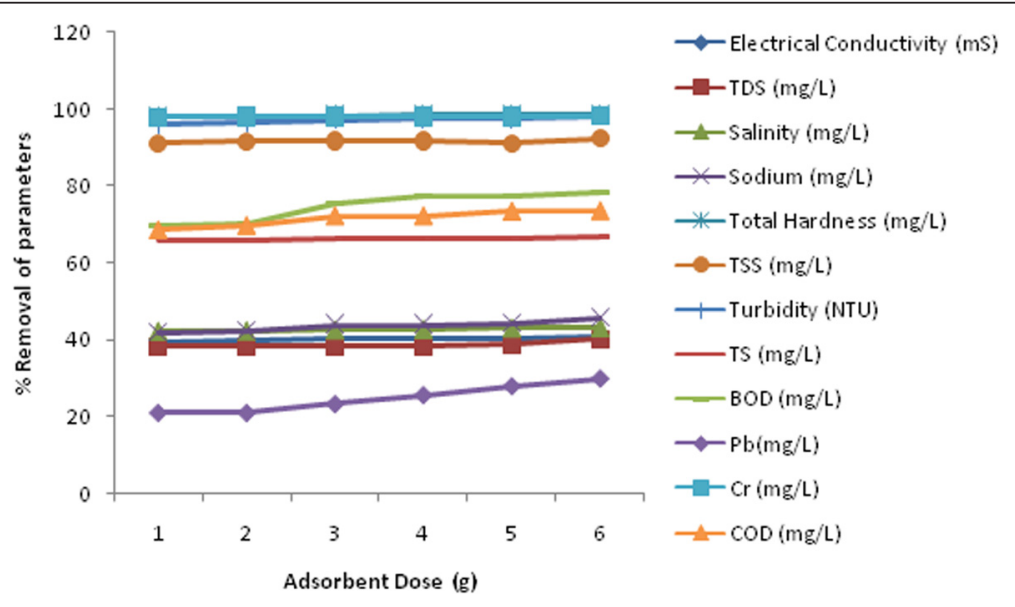

Fig. 5 Effect of adsorbent dose on removal percentage (\%) of some physicochemical parameters 


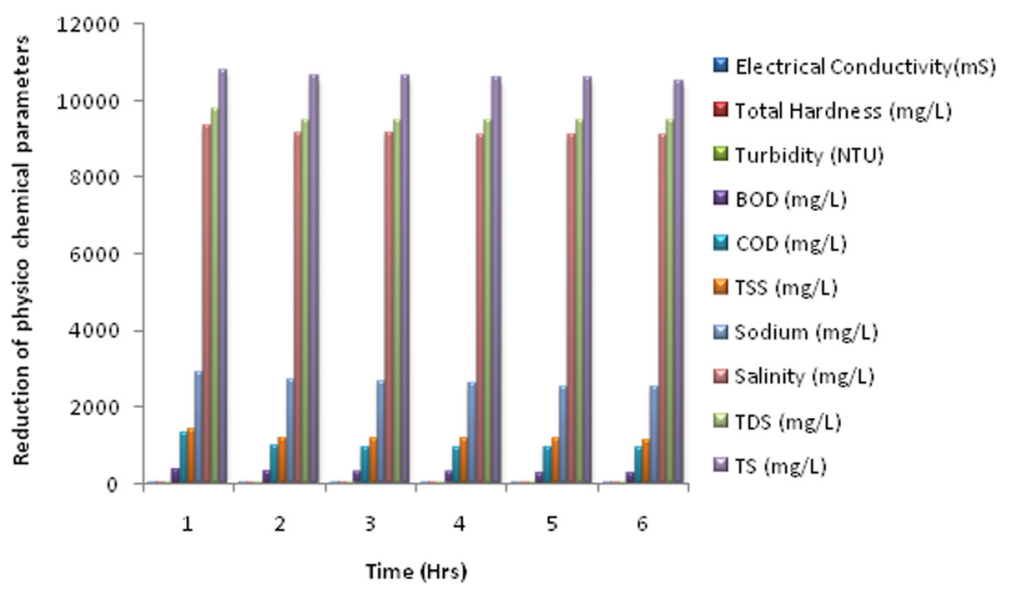

Fig. 6 Effect of time on reduction of physicochemical parameters

open land and surrounding water bodies (Govil et al. 2004). This sample was collected in a plastic container and kept in the refrigerator at $4{ }^{\circ} \mathrm{C}$, and the effluent was used for the experiment for the next day of sample collection.

\section{Physicochemical study}

The samples thus collected were analysed for total solids (TS), total dissolved solids (TDS), total suspended solids (TSS), biochemical oxygen demand (BOD), chemical oxygen demand (COD), total hardness, salinity, turbidity, electrical conductivity and presence of heavy metals like chromium and lead. The techniques and methods followed for analysis and interpretation of physicochemical parameters are those given by APHA (1995) and heavy metals by atomic absorption spectroscopy.

\section{Results and discussion}

The mean values for each parameter of the wastewater revealed that most of them were beyond the standard provisional limit provided by ISI (1991), CPCB as shown in Table 1.

\section{Effect of $\mathrm{pH}$}

$\mathrm{pH}$ is the most important factor that affects the adsorption process. The effect of $\mathrm{pH}$ of tannery effluent on adsorption was investigated from $\mathrm{pH} 2-8$ (Figs. 1 and 2). It was found that the reduction of physicochemical parameters and heavy metal ions were higher at low $\mathrm{pH}$. This was due to the fact that low $\mathrm{pH}$ causes surface $\mathrm{OH}^{-}$ groups to accept protons, facilitating ligand exchange since $\mathrm{H}_{2} \mathrm{O}$ is an easier ligand than $\mathrm{OH}^{-}$to get displaced from metal bonding sites, and hence, low $\mathrm{pH}$ promotes anion adsorption (Dessalew D. Alemayehu et al. 2012).

In other words, at low $\mathrm{pH}$, a large number of hydrogen ions can neutralise the oppositely charged surface and thus enhance the electrostatic attraction between the adsorbent and adsorbate overcoming electrostatic repulsion between them (Vasanthy and Lakshmana Perumalsamy 1995). Moreover from the literature, at low $\mathrm{pH}$, the

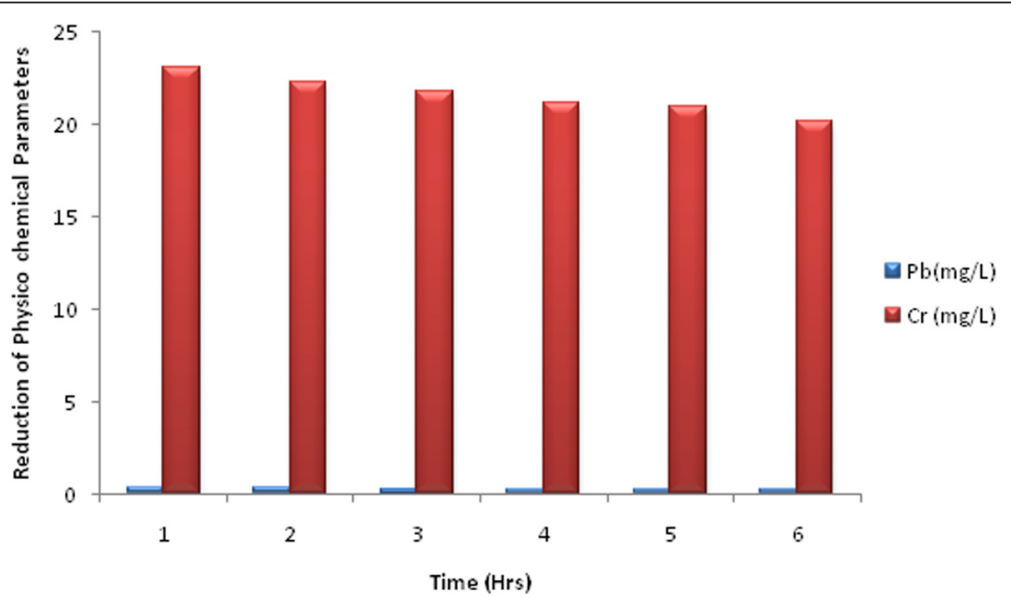

Fig. 7 Effect of time on removal of metal ions 


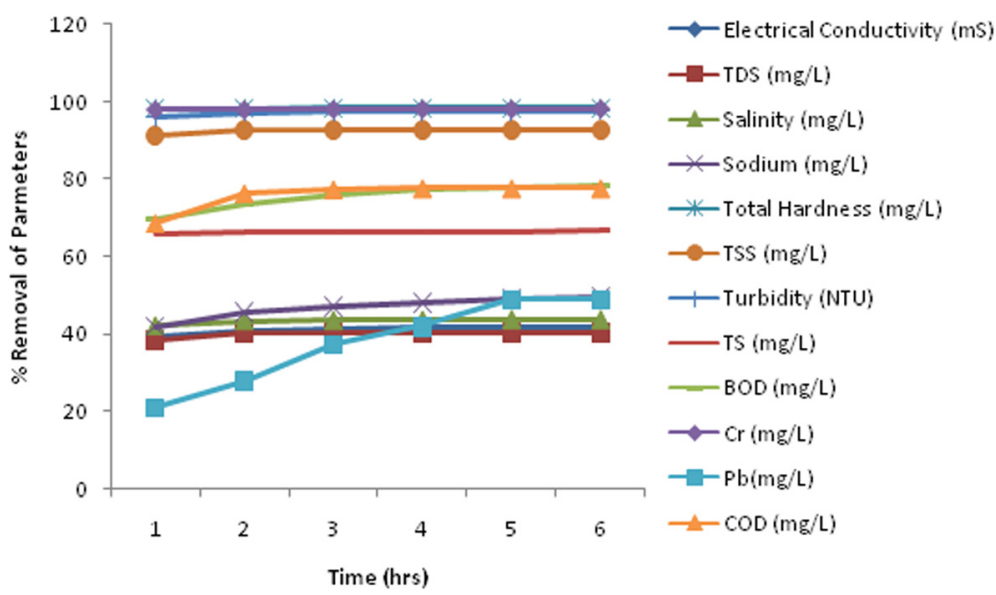

Fig. 8 Effect of time on removal percentage (\%) of some physicochemical parameters

spontaneous reduction of $\mathrm{Cr}(\mathrm{VI})$ into $\mathrm{Cr}(\mathrm{III})$ also occurred due to high redox potential $(1.3 \mathrm{~V})$, and hence, chromium(VI) has been removed up to $97 \%$ (Bhaumik et al. 2012; Karthik and Meenakshi 2014). Lead showed a minimal of $21 \%$ removal efficiency, and this may be due to intervention of other ions which were also present in the effluent. The optimum $\mathrm{pH} 3$ was selected for further experiments.

\section{Effect of adsorbent dose}

The effect of adsorbent dose was studied by varying dosage from 1-6 g with the optimum pH 3 (Figs. 3 and 4). With the increase of adsorbent dose, the reduction of physicochemical parameters and the removal of heavy metal ions increased up to $5 \mathrm{~g}$. This was due to the increased available binding sites in the nanocomposite for the complexation of metal ions (Saravanan et al. 2013). Equilibrium was almost attained after $5 \mathrm{~g}$ of adsorbent dosage as a result of decrease in available sites in the adsorbent. The maximum removal percentage (\%) obtained in $5 \mathrm{~g}$ of dose for all parameters is shown in Fig. 5. The highest removal efficiencies for different chemical parameters achieved were 78 \% (BOD), 73 \% (COD), $91 \%$ (TSS), $39 \%$ (TDS), $98 \%$ (Cr), $99 \%$ (total hardness), and $28 \%(\mathrm{~Pb}), 40 \%$ (electrical conductivity), $43 \%$ (salinity), $45 \%$ (sodium), 66 \% (TS) and $98 \%$ (turbidity).

\section{Effect of time}

The effect of contact time on the reduction of physicochemical parameters was determined by varying time from 1-6 h (Figs. 6 and 7) at pH 3. The dependency of removal efficiency of some physicochemical parameters on reaction time is shown in Fig. 8. The highest removal efficiencies for different chemical parameters achieved were 77 \% (BOD), 78 \% (COD), 93 \% (TSS), 41 \% (TDS), $98 \%(\mathrm{Cr}), 98 \%$ (total hardness), and $42 \%(\mathrm{~Pb}), 42 \%$ (electrical conductivity), $44 \%$ (salinity), $48 \%$ (sodium), $67 \%$ (TS) and $98 \%$ (turbidity).

The reduction efficiency increased rapidly till $240 \mathrm{~min}$. There was no significant change in equilibrium concentration after $240-360$ min since the adsorption phase reached equilibrium. A faster initial removal rate was possibly due to the availability of sufficient vacant adsorbing sites in the adsorbent. Afterwards, the rate of removal decreased significantly due to availability of limited vacant adsorption sites (Sivakami et al. 2013).

Table 2 Physical and chemical characteristics of the untreated and treated effluent

\begin{tabular}{|c|c|c|}
\hline Parameters & Untreated effluent & Treated at $\mathrm{pH} 3$ \\
\hline \multicolumn{3}{|l|}{ Physical parameters } \\
\hline Colour & Blackish colour & Colourless \\
\hline Odour & Disagreeable smell & Odourless \\
\hline \multicolumn{3}{|l|}{ Chemical parameters } \\
\hline Electrical conductivity $(\mathrm{mS} / \mathrm{cm})$ & 27.3 & 16.6 \\
\hline $\begin{array}{l}\text { Biochemical oxygen demand } \\
\text { (BOD) (mg/l) }\end{array}$ & 1250 & 380 \\
\hline $\begin{array}{l}\text { Chemical oxygen demand } \\
\text { (COD) (mg/l) }\end{array}$ & 4210 & 1320 \\
\hline Total dissolved solids (TDS) (mg/l) & 15,900 & 9800 \\
\hline Total solids (TS) (mg/l) & 31,740 & 10,800 \\
\hline Total hardness (TH) (mg/l) & 923 & 16 \\
\hline Salinity (mg/l) & 16,200 & 9360 \\
\hline Turbidity (NTU) & 453 & 18 \\
\hline Sodium (mg/l) & 5000 & 2900 \\
\hline Chromium (Cr) (mg/l) & 1055 & 23.05 \\
\hline Lead $(\mathrm{Pb})(\mathrm{mg} / \mathrm{l})$ & 0.43 & 0.34 \\
\hline
\end{tabular}




\section{Comparison of treated effluent with the raw effluent}

The comparative study for some effluent quality parameters of the raw effluent and the treated effluent is presented in Table 2 where the treated effluent was mentioned at $\mathrm{pH} 3$. The concentration of total chromium drops down from 1055 to $23.05 \mathrm{mg} / \mathrm{l}$ with a removal of $97.81 \%$ of chromium, and hence, it is obvious that a chromium concentration has been reduced to a large extent by using Cs-g-PBA/bent nanocomposite. The concentration of lead was reduced from 0.43 to $0.34 \mathrm{mg} / \mathrm{l}$ with a removal percentage of $20.93 \%$. Electrical conductivity was also decreased to $39.19 \%$ and cannot be reduced to a greater extent as observed in the case of chromium concentration. This might be due to some ionic species which do not get precipitated (Sabur et al. 2013). The initial value of COD was $4210 \mathrm{mg} / \mathrm{l}$, and after treatment, it was decreased to 1320 and the percentage removed is $68.64 \%$. BOD was reduced from 1250 to $380 \mathrm{mg} / \mathrm{l}$. TSS was removed to $91.16 \%$ and TS to $65.97 \%$. Turbidity was removed from 453 to 18 NTU.

\section{Conclusions}

Though tannery is an indispensable industry for the economic and social growth of a country, the fact that the wastewater generated by these industries gets directly discharged into the nearby water body with insufficient treatment is alarming. Most of the physicochemical parameters investigated in this study showed that almost all the effluent characteristics were above the provisional discharge limit set by ISI. In the present study, experiments have been conducted for the removal of $\mathrm{Cr}(\mathrm{VI})$ and $\mathrm{Pb}$ (II) from the tannery industrial wastewater using Cs-gPBA/bent nanocomposite as an adsorbent. To know the ability of Cs-g-PBA/bent, the experiments were conducted with varying adsorbent dosage, contact time and $\mathrm{pH}$.

The results showed that the maximum removal percentage of $\mathrm{Cr}(\mathrm{VI})$ in the tannery industrial wastewater at an optimum adsorbent dosage of $5 \mathrm{~g}$, contact time of 240 min and $\mathrm{pH}$ of 3 was $97.81 \%$. Also, the resultant maximum removal percentage of $\mathrm{Cr}(\mathrm{VI})$ in tannery industry wastewater with optimum processing parameters was verified with the other physicochemical parameters of BOD, COD, total hardness, TDS, TSS, TS, salinity, turbidity, electrical conductivity and sodium in the tannery industry wastewater. Further, it was understood that the various pollutants of tannery wastewater like hexavalent chromium, total hardness, TSS and turbidity were reduced to the maximum extent of satisfaction with a comparatively economical absorption process. As this process is promising, it can be concluded that chitosan-g-poly (butyl acrylate)/bentonite nanocomposite is more effective for removal of heavy metals and reduction of concentration of physicochemical parameters from the tannery effluent.

\section{Competing interests}

The authors declare that they have no competing interests.

\section{Authors' contributions}

PNS and RN contributed to the conception and design of the study. RN carried out the experiments, analysed the data and drafted the manuscript, and PNS supervised the works. Both authors read and approved the final manuscript.

Received: 17 December 2015 Accepted: 30 April 2016

Published online: 21 May 2016

\section{References}

Abdel Khalek, M.A., Mahmoud, G.A., El-Kelesh, N.A. (2012). Synthesis and Characterization of Poly-Methacrylic Acid Grafted Chitosan-Bentonite Composite and its Application for Heavy Metals Recovery. Chemistry and Materials Research, 2(7), 1-12.

Alemayehu, D. D., Singh, S. K., \& Tessema, D. A. (2012). Assessment of the adsorption capacities of fired clay soils from JIMMA (Ethiopia) for the removal of $\mathrm{Cr}(\mathrm{VI})$ from aqueous solution. Universal Journal of Environmental Research and Technology, 2(5), 411-420.

American Public Health Association (APHA). (1995). Standard methods for estimation of water and wastewater (19th ed.). Washington: American Water Works Association, Water environment Federation. application as electrochemical sensors.

Anirudhan, T. S., Rijith, S., \& Tharun, A. R. (2010). Adsorptive removal of thorium(IV) from aqueous solutions using poly(methacrylic acid)-grafted chitosan/bentonite composite matrix: process design and equilibrium studies. Colloids and Surfaces A: Physicochem. Eng. Aspects, 368, 13-22.

Bhaumik, M., Maity, A., Srinivasu, V. V., \& Onyango, M. S. (2011). Enhanced removal of $\mathrm{Cr}(\mathrm{VI})$ from aqueous solution using polypyrrole/ $/ \mathrm{Fe}_{3} \mathrm{O}_{4}$ magnetic nanocomposite. Journal of Hazardous Materials, 190, 381-390.

Bhaumik, M., Maity, A., Srinivasu, V. V., \& Onyango, M. S. (2012). Removal of hexavalent chromium from aqueous solution using polypyrrole-polyaniline nanofibers. Chemical Engineering Journal, 181-182, 323-333.

Central Pollution Control Board. (1986). Pollution Control Acts, Rules, and Notifications issued there under. Fourth edition (pp. 358-359). New Delhi: CPCB, Ministry of Environment and Forests. 897 pp.

Darder, M., Colilla, M., \& Ruiz-Hitzky, E. (2005). Chitosan-clay nanocomposites: application as electrochemical sensors. Applied Clay Science, 28, 199-208.

Govil, P. K., Reddy, G. L. N., Krishna, A. K., Seshu, C. L. V., Satya Priya, V., \& Sujatha, D. (2004). Inventorization of contaminated sites in India (NGRI technical report, pp. 54-66).

Guidelines for Drinking-Water Quality (2006) In (3rd Eds.). Geneva: World Health Organization

Indian Standard Institute (ISI). (1991). Drinking Water Specification'.

Junping, Z., Li, W., \& Aiqin, W. (2007). Preparation and properties of chitosan-gpoly(acrylic acid)/montmorillonite superabsorbent nanocomposite via in situ intercalative polymerization. Industrial and Engineering Chemistry Research, 46, 2497-2502.

Karthik, R., \& Meenakshi, S. (2014). Removal of hexavalent chromium ions from aqueous solution using chitosan/polypyrrole composite. Desalination and Water Treatment, 1-14.

Kushwaha, A.K., Gupta, N., Chattopadhyaya, M.C. (2012). Adsorption behavior of lead onto a new class of functionalized silica gel. Arabian Journal of Chemistry, xxx, Xxx-Xxx. DOI:10.1016/j.arabjc.2012.06.010

Mi, F. L., Tan, Y. C., Liang, H. F., \& Sung, H. W. (2002). In vivo biocompatibility and degradability of a novel injectable-chitosan-based implant. Biomaterials, 23, 81-91.

Mishra, D. M., Tripathy, J., Srivastava, A., Mishra, M. M., \& Behari, K. (2008). Graft copolymer (chitosan-g-N-vinyl formamide): synthesis and study of its properties like swelling, metal ion uptake and flocculation. Carbohydrate Polymers, 74, 632-639.

Mouzdahir, Y. E. I., Elmchaouri, A., Mahboub, R., Gil, A., \& Korili, S. A. (2010). Equilibrium modelling for adsorption of methylene blue from aqueous solutions on activated clay minerals. Desalination, 250, 335-338.

Needleman, H.L. (1999). History of lead poisoning in the world. In: Proceedings of international conference on lead poisoning prevention and treatment: 8-10 Febrauary, 1999. (pp. 17-25). Bangalore, India: The George foundation.

Raji, C., \& Anirudhan, T. S. (1998). Batch Cr(VI) removal by poly acrylamide-grafted sawdust: kinetics and thermodynamics. Water Research, 32, 3772. 
Ravi Kumar, M. N. V. (2000). A review of chitin and chitosan applications. Reactive and Functional Polymers, 46, 1-27.

Sabur, M. A., Rahman, M. M., \& Safiullah, S. (2013). Treatment of tannery effluent by locally available commercial grade lime. Journal of Scientific Research, 5(1), 143-150.

Saravanan, D., Gomathi, T., \& Sudha, P. N. (2013). Sorption studies on heavy metal removal using chitin/bentonite biocomposite. International Journal of Biological Macromolecules, 53, 67-71.

Schütz, T., Dolinská, S., \& Mockovčiaková, A. (2013). Characterization of bentonite modified by manganese oxides. Universal Journal of Geoscience, 1(2), 114-119.

Sivakami, M. S., Gomathi, T., Venkatesan, J., Jeong, H.-S., Kim, S.-K., \& Sudha, P. N. (2013). Preparation and characterization of nano chitosan for treatment wastewaters. International Journal of Biological Macromolecules, 57, 204-212.

Srivastava, A., Mishra, D. M., Tripathy, J., \& Behari, K. (2009). One pot synthesis of xanthan gum-g-N-vinyl-2-pyrrolidone and study of their metal ion sorption behavior and water swelling property. Journal of Applied Polymer Science, $111,2872-2880$.

Thambiannan, S., Rajendran, R., \& Lima Rose, M. (2013). Clean—soil, air. Water, 41, 797-807.

Vanamudan, A., Bandwala, K., \& Pamidimukkala, P. (2014). Adsorption property of rhodamine $6 \mathrm{G}$ onto chitosan-g-(N-vinylpyrrolidone)/montmorillonite composite. International Journal of Biological Macromolecules, 69, 506-513.

Vasanthy, M., \& Lakshmana Perumalsamy, P. (1995). Removal of chromium using various adsorbents. Journal of Ecotoxicology and Environmental Monitoring, $3,47-50$.

Wang, X., Yang, L., Zhang, J., Wang, C., \& Li, Q. (2014). Preparation and characterization of chitosan-poly(vinyl alcohol)/bentonite nanocomposites for adsorption of $\mathrm{Hg}(\mathrm{II})$ ions. Chemical Engineering Journal, 251, 404-412.

\section{Submit your manuscript to a SpringerOpen ${ }^{\odot}$ journal and benefit from:}

- Convenient online submission

- Rigorous peer review

- Immediate publication on acceptance

- Open access: articles freely available online

- High visibility within the field

- Retaining the copyright to your article

Submit your next manuscript at $\gg$ springeropen.com 